\section{The Cape Naturalist}

IN November there appeared the first number of the Cape Naturalist, which is designed to increase the interest of non-technical readers in Nature and archæology in South Africa. A striking cover reproduces the flower of Stapelia, the colour and carrion. like odour of which attracts blowflies which pollinate the flowers, and sometimes, deceived by the smell, deposit their eggs upon the petals. The articles are short and varied enough to make a general appeal (Pp. 24, price 7d. post free, from Mrs. Stephens, Alma Road, Rosebank, Cape Town.). The magazine is issued by the Cape Natural History Club, and should it meet a demand it will be issued quarterly, or possibly in time monthly.

\section{International Hospital Congress}

THE Fourth International Hospital Congress, which has been organised by the Italian Government, will be held at Rome on May 5-12, when the following subjects among others will be discussed : the hospital as part of a system of public health ; the equipment and technical installation of hospitals ; the work of the hospital and its protection in times of disaster. The Congress will be preceded by a tour of inspection of some of the large towns in northern Italy, and be followed by excursions in southern Italy, Sicily and Tripoli. Further information can be obtained from the International Hospital Association, Lucerne, Switzerland.

\section{First Comet of 1935}

A message published in The Times of January 10 announces that a comet has been discovered by Mr. E. L. Johnson of the Union Observatory, Johannesburg. This comet will be called Johnson's comet, $1935 \mathrm{~A}$. The comet is presumably faint. Some half dozen faint comets are seen every year. For example, in 1933 there were six, ranging in magnitude at brightest from 8 to 18 (this was the faintest comet which has yet been observed). Of these, three were periodic and recognised as returns of known comets. It is some years since a notable, naked-eye comet appeared.

\section{Scientific Meetings in Australia}

MANY of the Australian scientific societies have arranged meetings for January in Melbourne, the natural centre during its centenary celebrations for conferences and congresses of all kinds. The Australian National Research Council held its annual session on January 15, when important questions of future policy were debated. It has been suggested that its scope be altered somewhat, and that it take the title of Royal Society of Australia, recently bestowed on a smaller scientific society established at Canberra. On January 16-23 the Australian and New Zealand Association for the Advancement of Science is holding its biennial meeting under the presidency of Sir Douglas Mawson. Public addresses are being delivered by Dr. P. Marshall on volcanoes of the Pacific and by Sir George Julius on certain aspects of the unemployment problem. Sir David Orme Masson is giving the Liversidge Memorial
Lecture to Section B on crucial advances in chemical theory during the last half century. Immediately following these sessions, the half-yearly meeting of the Council for Scientific and Industrial Research will take place: while many minor societies and groups of workers are arranging gatherings for discussion of matters of common interest.

\section{Announcements}

Tre Council of the Physical Society has awarded the twelfth Duddell Medal to Dr. W. Ewart Williams, lecturer in physics at King's College, London.

We regret to announce the death, on January 13 . of the Rev. S. A. McDowall, chaplain and senior science master at Winchester College, aged fifty-two years.

The Huxley Memorial Lecture of the Royal College of Science, South Kensington, for 1935 will be delivered on May 6 by Sir Henry Dale, director of the National Institute for Medical Research, who has chosen as his subject "Viruses and Heterogenesis: an old Problem in a new Form".

THE following appointments have recently been made by the Secretary of State for the Colonies: Mr. M. W. Gibbon, Mr. J. R. Miller and Mr. E. W. Momber, to be superintendents of agriculture, Nigeria; Mr. W. F. Baldock (assistant conservator of forests), to be senior assistant conservator of forests, Tanganyika; Mr. C. B. Bisset (assistant geologist, Nyasaland), to be field geologist, Uganda ; Mr. A. de K. Frampton (agricultural superintendent, British Guiana), to be agricultural officer, Straits Settlements and Federated Malay States; Mr. G. L. R. Hancock (assistant entomologist, Agricultural Department), to be biologist, Makerere College, Uganda ; Mr. E. F. Peck (veterinary officer, Nigeria), to be veterinary and agricultural officer, Somaliland; Mr. C. Smith (deputy conservator of Forests, Federated Malay States), to be conservator of forests, Johore; Mr. A. J. Wakefield (senior agricultural officer), to be deputy director of agriculture, Tanganyika.

Applications are invited for the following appointments, on or before the dates mentioned:-An agricultural lecturer and warden at the Kent Farm Institute, Borden, Sittingbourne (Jan. 21). Teachers of science subjects and mathematics and engineering at the Willesden Technical College-The Secretary, Willesden Local Higher Education Committee, Education Office, Dyne Road, Kilburn, N.W.6 (Jan. 25). A head of the Junior Technical School for Boys, North-Western Polytechnic, Prince of Wales Road, Kentish Town, London, N.W.5-The Clerk to the Governors (Jan. 31). A veterinary pathologist in Malta-The Director of Recruitment (Colonial Service), 2 Richmond Terrace, Whitehall, S.W.I (Jan. 31). An assistant entomologist at the Rothamsted Experimental Station, Harpenden, Herts-The Secretary (Feb. 15). A professor of botany in the Egyptian University, Abbasia, Cairo-The Dean of the Faculty of Science (March 15). 